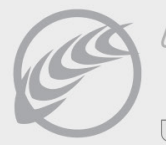

\title{
Production of Functional Cookies and Quality Research
}

\author{
A.V. Ghazaryan, S.I. Sagradyan \\ Armenian National Agrarian University \\ astghikghazaryan888@gmail.com, silvasahradyan@rambler.ru
}

\section{ART I CLE INFO}

Keywords:

cookies,

red currant powder,

stevioside,

technology,

quality,

minerals

\begin{abstract}
A B S T R A C T
A technology for getting new assortment of functional cookies has been developed in the current work, which are intended for the use in special diets and for wide range of consumption. The quality indicators of these cookies were determined, and it turned out that the mentioned indices regulated per the standard fully meet the requirements set upon the Normative Documents. At the same time, it has been disclosed that the new cookies are enriched with iron, calcium, phosphorus, potassium, magnesium and vitamins $C, B_{1}, B_{2}$ and $B_{6}$.
\end{abstract}

\section{Introduction}

Currently, there are many definitions of functional food presented in the normative documents and in the professional literature (GOST R 52349-2005, GOST R 55577-2013, Decree of RF 379-2018, Loktev and Zonova, 2019). As a result of the study, the interpretation of Loktev and Zonova on "functional food" have been proved as the most acceptable. All products are functional to some extent, because they all have a certain nutritional value. Currently, food products are being intensively researched for additional physiological benefits that can reduce the risk of chronic diseases or optimize health otherwise. Due to such studies the global interest in the food types called "functional foods" has significantly increased.

Another term that is often used as a synonym for functional foods is "nutraceuticals". The term, introduced in 1991 by the Foundation for Innovations in Medicine, refers to almost any biologically active component that benefits health (Loktev and Zonova, 2019). At the present stage, some of the most important tasks in the confectionery industry are saving expensive raw materials, expanding the product range and improving technology. It is necessary to offer the consumer qualitatively new products using nontraditional raw materials with high consumer properties and low cost. Now it is relevant to develop food recipes for specialty foods, particularly for people suffering from diabetes and obesity (Matveeva and Koryachkina, 2012). There are more than 100 officially registered confectionery enterprises in Armenia; anyhow, almost none of them produce functional confectionery for the above-mentioned purposes. The largest cookie suppliers to Armenia are from Russia, Ukraine, Poland, Germany, Spain, 80 \% being from Russia. To obtain functional cookies, the powder of red currant (Ribes rubrum), growing in the RA, has been used as a source of vitamins, minerals, organic acids and pectin substances and stevioside has been used as a sugar substitute. In cookies, sugar is completely replaced with stevioside, since it enables to get a product with closeto-sucrose sweetness but that is harmless for health. The 
complete replacement of sugar with stevioside is due to the fact that new products can be regularly consumed by people with diabetes, overweight and those generally taking care of their health. In 2006, The World Health Organization made a clear conclusion: the plant of "Stevia rebaudiana Bertoni" is curative and absolutely safe. Currently, "Bertoni" candyleaf herbs are also grown in Armenia. Stevioside is the main active element of candyleaf, which is an extract refined therefrom. It is a water-soluble, white, crystalline, sweet natural herbal sweetener. Stevioside is not simply a sugar substitute, but it is also a substance rich in vitamins, minerals, polyunsaturated fatty acids and has a number of advantages such as low-calorie (10 kcal); so, it is fully fit for people preferring healthy diet.

In Armenia there are 6 types of natural currants: Eastern, Alpine, Biberstein, Armenian, Akhuryan and Common. In Armenia, the Common Red Currant is widespread, which is rich in pectin, mineral substances and vitamin $C$ (the vitamin content is $30-60 \mathrm{mg} \%$ ) that are vital for human organism. These nutrients are elements of functional significance, and cookies prepared via their addition will be considered as functional food products.

The aim of the current work is to develop a new technology for the production of new types of sacrose-free cookies that will have functional properties and contain vitamins, useful minerals, organic acids and will be fit for general consumption, children, diabetics and overweight people.

\section{Materials and methods}

The powder manufactured from the wild-growing Common Red Current through the well-known technologies was used as an additive for the new cookies (Antipov and Zhashkov, 2010). Stevioside powder "Stivia" of the "Stevilight Fitoe" trademark was used in the manufacture of functional cookies with red currant. In the current research work, $200 \mathrm{~g}$ of granulated sugar was replaced with $10 \mathrm{~g}$ stevioside. Based on numerous preliminary experiments, the optimal dose of red currant powder was determined guided by the averaged data obtained as a result of the 5-point system evaluation. The experimental options were:

Sample 1 - butter cookies (control)

Sample 2 - functional butter cookies with $10 \%$ red currant powder and stevioside

Sample 3 - functional butter cookies with stevioside

Sample 4 - functional butter cookies with $15 \%$ red currant jelly and stevioside.

Cookies with berry powder and stevioside were subjected to sensory examination, besides, berry powder was added in the butter cookie with the dose of $5 \%, 10 \%$ and $15 \%$. Then, expert examination on the sensory indicators for the produced cookies was carried out by a degustation committee consisting of 7 people. For further examinations, the cookie scoring high point (4.8) was selected. The physical and chemical properties, content of minerals and vitamins, as well as other indices regulated per the standard of functional cookies was determined (Skuratovskaya, 2003). Laboratory examinations were conducted in the SanitaryHygienic Laboratory of "National Institute of Health named after Academician S. Kh. Avdalbekyan" CJSC (Ministry of Health of the RA).

\section{Results and discussions}

For the production of functional cookies, the following ingredients were used: high-grade wheat flour, red currant powder, stevioside, butter, melange, water and the mixture of $\left(\mathrm{NH}_{4}\right)_{2} \mathrm{CO}_{3}$ and $\mathrm{NaHCO}_{3}$ as baking powder. To prepare the dough, the butter and stevioside was mixed for $t=10-15$ minutes, then the other raw products fixed upon the recipe were gradually added. Currant powder is added prior to flour, so as the powder is homogeneously mixed throughout the entire dough mass. The moisture content of the dough at $T=19-22{ }^{\circ} \mathrm{C}$ made $15-24 \%$, after which the dough forming process was implemented. Baking lasted $t=5-12$ minutes in the oven chambers at $T=180-200^{\circ} \mathrm{C}$, then the baked products were cooled and moved to the production tare with the help of a scraper. The degustation committee assessed functional cookies supplemented with various portions of red currant and stevioside through 5-point assessment system (per the organoleptic indicators) (Table 1).

As a result of the organoleptic examination (Table 1) the maximum rating was awarded to the functional cookie containing $10 \%$ red currant powder. The results obtained indicate that the functional cookies with berry powders and stevioside are of high quality per their organoleptic indices and the latter are, if not always, a priority for the consumers.

The results of the physicochemical indicators of functional cookies were compared with the standard indices (GOST 24901-2014. (2019)) and it was proved that they fully meet the requirements of Normative Documents (Table 2). The chemical composition of the produced cookies was also determined: mass fractions of protein substances, carbohydrates, sucrose, fat, total ash (Table 3).

The mass fractions of minerals and vitamins $C, B_{1}, B_{2}, B_{6}$ of the studied cookies were also estimated (Table 4). 
Table 1. Evaluation of functional cookies with red currant and stevioside*

\begin{tabular}{|l|c|c|c|c|}
\hline \multirow{2}{*}{ Organoleptic indicators } & \multicolumn{4}{|c|}{ Cookies with stevioside and different doses of red currant powder } \\
\cline { 2 - 5 } & control sample & $\mathbf{5 \%}$ red currant powder & $\mathbf{1 0}$ \% red currant powder & $\mathbf{1 5} \%$ red currant powder \\
\hline Appearance & 1.0 & 1.0 & 1.2 & 1.2 \\
Colour & 0.6 & 0.6 & 1.0 & 1.1 \\
\hline Taste and flavor & 1.6 & 1.9 & 2.2 & 1.5 \\
\hline Appearance in the fracture & 0.4 & 0.4 & 0.4 & 0.5 \\
\hline Total & 3.6 & 3.9 & 4.8 & 4.3 \\
\hline
\end{tabular}

Table 2. The results of physicochemical examinations of cookies*

\begin{tabular}{|c|c|c|c|c|c|}
\hline \multirow{2}{*}{$\begin{array}{l}\text { Samples } \\
\text { Indicators }\end{array}$} & \multicolumn{5}{|c|}{ Cookies } \\
\hline & N1 & N2 & N3 & N4 & $\begin{array}{c}\text { According to } \\
\text { GOST-24901- } \\
2014 \text { (2019) }\end{array}$ \\
\hline Humidity, \% & 4.3 & 5.8 & 3.7 & 19.3 & $\begin{array}{l}\text { no more } \\
\text { than } 15.5\end{array}$ \\
\hline $\begin{array}{l}\text { Mass fraction } \\
\text { of fat in terms } \\
\text { of dry matters, } \\
\%\end{array}$ & 12.0 & 15.0 & 12.0 & 12.0 & $\begin{array}{l}\text { no less } \\
\text { than } 2.3\end{array}$ \\
\hline $\begin{array}{l}10 \% H C L \\
\text { insoluble mass } \\
\text { of ash fraction, } \\
\%\end{array}$ & 0.045 & 0.02 & 0.03 & 0.05 & $\begin{array}{l}\text { no more } \\
\text { than } 0.1\end{array}$ \\
\hline Wettability, \% & 160 & 165 & 160 & 165 & $\begin{array}{c}\text { no less } \\
\text { than } 150\end{array}$ \\
\hline $\begin{array}{l}\text { Alkalinity, } \\
\text { degree }\end{array}$ & 2.0 & 1.9 & 2.0 & 1.85 & $\begin{array}{l}\text { no more } \\
\text { than } 2.0\end{array}$ \\
\hline
\end{tabular}

Table 4. The content of minerals and vitamins of functional red currant cookies*

\begin{tabular}{|l|c|c|c|c|}
\hline $\begin{array}{c}\text { Minerals and vitamins, } \\
\text { mg\% }\end{array}$ & \multicolumn{4}{|c}{ Cookies } \\
\hline $\mathrm{K}$ & $\mathbf{N 1}$ & $\mathbf{N 2}$ & $\mathbf{N 3}$ & $\mathbf{N 4}$ \\
$\mathrm{Na}$ & 106.7 & 212 & 135.6 & 186.3 \\
$\mathrm{Ca}$ & 13.3 & 15.0 & 15.7 & 18.0 \\
$\mathrm{Mg}$ & 8.0 & 15.4 & 6.8 & 7.0 \\
\hline $\mathrm{P}$ & 8.7 & 9.85 & 7.2 & 8.0 \\
$\mathrm{Fe}$ & 79.3 & 91.3 & 80.3 & 60 \\
$\mathrm{Vitamin} C$ & 0.97 & 1.27 & 0.65 & 0.7 \\
\hline Vitamin $B_{1}$ & 0.0 & 0.1 & 0.0 & 7.0 \\
\hline Vitamin $B_{2}$ & 0.20 & 0.22 & 0.20 & 0.25 \\
\hline Vitamin $B_{6}$ & 0.08 & 0.08 & 0.09 & 0.11 \\
\hline Energy value. kcal & 0.18 & 0.19 & 0.18 & 0.28 \\
\hline *Composed by the authors. & 441.4 & 449.7 & 441.6 & 441.4 \\
\hline
\end{tabular}

Table 3. The examination results of the chemical composition of cookies*

\begin{tabular}{|l|c|c|c|c|}
\hline \multicolumn{1}{|c|}{ Indicators } & \multicolumn{4}{|c|}{ Cookies } \\
\hline & N1 & N2 & N3 & N4 \\
\hline $\begin{array}{l}\text { Mass fraction of } \\
\text { moisture, \% }\end{array}$ & 4.3 & 5.8 & 3.7 & 19.3 \\
\hline $\begin{array}{l}\text { Mass fraction of } \\
\text { protein, \% }\end{array}$ & 8.14 & 8.70 & 8.90 & 8.70 \\
\hline $\begin{array}{l}\text { Mass fraction of } \\
\text { carbohydrates, \% }\end{array}$ & 57.20 & 69.96 & 75.00 & 59.45 \\
\hline $\begin{array}{l}\text { Mass fraction of } \\
\text { sucrose, \% }\end{array}$ & 18.0 & - & - & - \\
\hline $\begin{array}{l}\text { Mass fraction of fat in } \\
\text { terms of dry matters, \% }\end{array}$ & 12.0 & 15.0 & 12.0 & 12.0 \\
\hline \begin{tabular}{l} 
Total ash, \% \\
\hline
\end{tabular} & 0.40 & 0.55 & 0.40 & 0.50 \\
\hline
\end{tabular}

The results of the examination show that functional cookies supplemented with $10 \%$ of red currant powder and red currant jelly are richer in minerals necessary for the human body as compared to those found in standard cookies. Thus, the content of $\mathrm{Fe}$ increased by $0.3 \mathrm{mg} \%, \mathrm{Na}$ - by $1.7 \mathrm{mg} \%, K$ - by $105.3 \mathrm{mg} \%, C a$ - by $7.4 \mathrm{mg} \%, P$ - by $12 \mathrm{mg} \%$ and $M g$ - by $1.15 \mathrm{mg} \%$. At the same time, they were enriched with vitamins, particularly with vitamin $C$. The content of vitamin $C$ is rather high in the jelly containing samples with $15 \%$ red currant powder. Functional cookies do not contain sucrose and the calorie content is lower compared to the standard samples (Table 4). Minerals are not only important for human food diet, but they also have a favorable effect on the bioactivities of microorganisms in the cookie dough. Interacting with the dough ingredients $\mathrm{Ca}$ and $\mathrm{Mg}$ improve the dough rheological properties. 


\section{Conclusion}

As a result of the conducted experiments, sweet dough (butter), high-quality functional cookies supplemented with red currant powder and stevioside rich in minerals and vitamins have been produced.

So, functional cookies do not contain sucrose and are intended for a wide-range consumption, including children, diabetics and overweight people.

\section{References}

1. Antipov, S.T., Zhashkov, A.A. (2010) Modern Technologies in the Production of Fruit and Berry Powders // Bulletin of TSTU. - V. 16. - No 4, - pp. 332-336 (in Russian).

2. Decree of the Federal Agency for Technical Regulation and Metrology of February 26, 2018 N 379 "On the Organization of the Activities of the Technical Committee for Standardization "Specialized Food Products" (in Russian).
3. GOST 24901-2014. (2019) Biscuits. General Technical Conditions. M., Standartinfo (in Russian).

4. GOST R 52349-2005. Foodstuffs. Functional Foods. Terms and Definitions (in Russian).

5. GOST R 55577-2013. Specialized and Functional Foodstuffs. Information about the Distinctive Signs and Efficiency Claims (in Russian).

6. Loktev, D.B., Zonova, L.N. (2019). Functional Products and their Role in Human Nutrition, - pp. 48-53. Available from: http://www.cyberleninka.ru/article/n/produktyfunktsionalnogo-naznacheniya-i-ih-rol-v-pitaniicheloveka (accessed on 20.09.2021).

7. Matveeva, T.V., Koryachkina, S.Ya. (2012). Physiologically Functional Food Ingredients for Bakery and Confectionery Products: Monograph, Orel: State University, UNPK, - 947 p. (in Russian).

8. Skuratovskaya, O.D. (2003). Product Quality Control with Physical and Chemical Methods. - V 2. Pastry, 2nd Issue. Reviewed and Extended, - M. DeLiprint, - 128 p. (in Russian). 